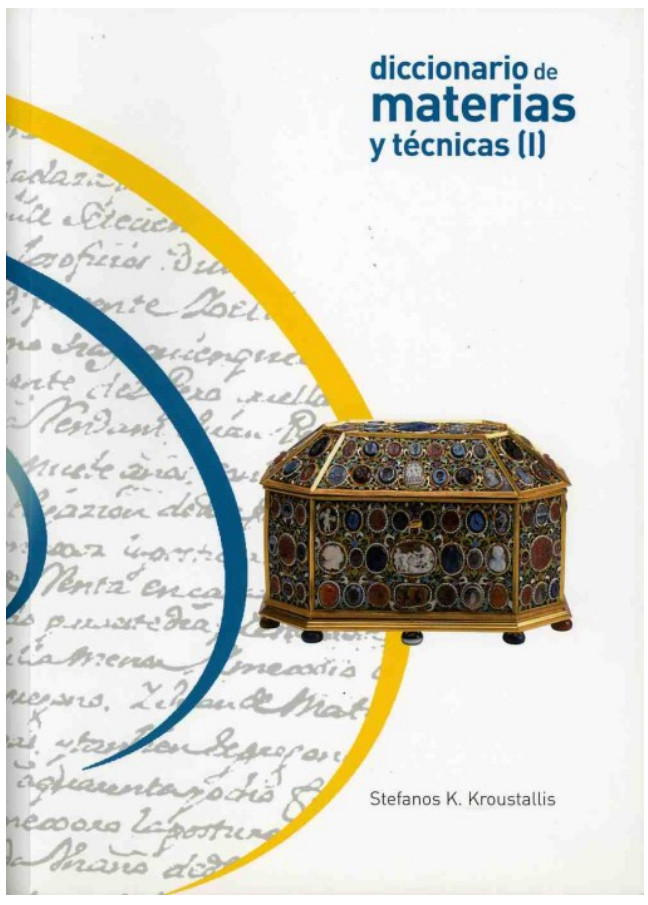

\section{Stefanos K. Kroustallis \\ Diccionario de materias y técnicas. \\ Tesauro para la descripción y catalogación de bienes culturales (I. Materias)}

\section{Secretaría General Técnica. Subdirección General de Publicaciones, Información y Documentación. Ministerio de Cultura Madrid, 2008}

732 páginas, $24 \times 17 \mathrm{~cm}$.

El Diccionario de Materias y Técnicas es un tesauro especializado en descripción y catalogación de bienes culturales promovido por la Subdirección General de Museos Estatales del Ministerio de Cultura. En el pasado año de 2008 se publicó la primera parte dedicada a las materias constitutivas de los bienes culturales y actualmente el autor trabaja en la segunda parte, el Diccionario de Técnicas.

La obra se estructura en dos secciones: el diccionario de materias y el tesauro propiamente dicho. En el primero se presentan los descriptores y los no-descriptores en orden alfabético con su correspondiente definición, nota de alcance y referencia bibliográfica y, en el caso de los no descriptores, el envío al descriptor correspondiente. El tesauro está formado por una estructura general con el índice y la presentación jerárquica, y un cuerpo de tesauro que desarrolla de forma esquemática y por orden alfabético las distintas relaciones posibles entre los términos. Consta de 3620 entradas, formadas por sustantivos, simples o compuestos, relativos a las sustancias físicas, naturales o transformadas por el hombre, que constituyen los bienes culturales. Cuenta además con una introducción en la que el autor describe las características, objetivos y estructura de la obra y los criterios adoptados para la selección, clasificación y asociaciones de los términos; un anexo documental gráfico con imágenes representativas de bienes culturales resaltando las materias de que están compuestos; y, por último, un apartado bibliográfico que incluye las obras consultadas.

El principal objetivo de la obra es proporcionar una herramienta de control terminológico que permita normalizar vocabularios y conceptos para los trabajos de catalogación realizados en los museos y colecciones, en especial aquellos que hayan adoptado el sistema Domus de documentación automatizado desarrollado por el Ministerio de Cultura. Su interés alcanza, sin embargo, a toda persona que quiera precisar términos y definiciones, no solo en documentación de bienes culturales, sino también en investigación, redacción de informes y proyectos técnicos y en consulta de carácter general.

Los descriptores son de carácter enciclopédico o descriptivo especializado, en cuyas definiciones incluye la identificación de la materia, su forma, características y propiedades naturales, en su caso el procesamiento de que haya sido objeto, el uso histórico y actual en las técnicas artísticas y las 
referencias bibliográficos. Como norma general, el autor prefiere como descriptores los nombres científicos frente a los de uso común, y los más actuales frente a los antiguos. Pero en algunas sustancias ha preferido el nombre común como descriptor en razón de ciertos criterios como "la continuidad de su uso, su vigencia, la proximidad al pensamiento de los usuarios, la ausencia de problemas de ambigüedades o de equívocos, así como los aspectos históricos y lingüísticos que conlleva su empleo." (p.23), lo que otorga un valor en sí a este criterio selectivo. También son interesantes las relaciones asociativas o jerárquicas, que se establecen a partir de tres indicadores clasificatorios: Materia según origen (a su vez desarrollado en Materia prima y Materia elaborada), Materia según función y Materia según forma. La relación asociativa permite distintos criterios para clasificar las materias y, por tanto, una lograda versatilidad, muy útil para obtener la información de manera precisa.

No existe en el idioma español ningún antecedente que coincida en la especificidad de este diccionario-tesauro. El autor ha tenido que apoyarse en otros de carácter temático como el Diccionario de Materiales Cerámicos (2002) y el Diccionario de Mobiliario (2005), publicados también por el Ministerio de Cultura, o el Diccionario del Dibujo y la Estampa (1996) de la Calcografía Nacional y la Real Academia de Bellas Artes de San Fernando; en diccionarios tecnológicos especializados, como, entre otros muchos, el de Ana Calvo sobre Conservación y Restauración (1997), el Vocabulario científico y técnico (2000), el Diccionario de Arquitectura y Construcción (2001) o el Diccionario Histórico de Telas y Tejidos (2004); en diccionarios científicos de química, botánica, mineralogía y zoología, o en diccionarios generales de arte, arqueología, arquitectura o artes decorativas. La extensa bibliografía aportada da cuenta del empleo de otras muy diversas fuentes, desde guías y manuales sobre técnicas artísticas y artesanales hasta estudios científico-técnicos sobre materias y objetos culturales.

En los textos de arte, en los documentos de catalogación y descripción museográficos e, incluso, en los textos e informes de conservación y restauración se cometen con frecuencia errores e imprecisiones en el uso de los términos sobre técnicas artísticas. Apremiaba, pues, la normalización de vocabularios en este campo, hasta ahora acometida muy parcialmente. La dificultad es grande porque muchos de los términos se vinculan a técnicas y procesos antiguos, cuya comprensión requiere labores de investigación en fuentes que todavía están por iniciarse. Con este diccionariotesauro se ha dado ya un gran paso porque se ha logrado reunir, actualizar y sistematizar una enorme cantidad de información dispersa y se facilita una herramienta de gran utilidad para toda persona que quiera precisar definiciones, no solo, como se ha dicho, para la documentación de bienes culturales, sino también para toda actividad interesada en el conocimiento de las técnicas artísticas.

Rocío Bruquetas Galán Instituto del Patrimonio Cultural de España 